\title{
NEUROLOGICAL SYMPTOMS OF VITAMIN B12 DEFICIENCY: ANALYSIS OF PEDIATRIC PATIENTS*
}

\author{
Hepsen Mine Serin ${ }^{1}$ and Elif Acar Arslan ${ }^{2}$ \\ ${ }^{1}$ Department of Pediatric Neurology, Ege University, School of Medicine, İzmir, Turkey; \\ ${ }^{2}$ Department of Pediatric Neurology, Karadeniz Technical University, School of Medicine, Trabzon, Turkey
}

\begin{abstract}
SUMMARY - Vitamin B12 is one of the essential vitamins that affect various systems in the body, including the central nervous system. Vitamin B12 plays an important part in the metabolism of the nervous system, although its exact role under pathological conditions is not fully understood. The purpose of this study was to emphasize the importance of early diagnosis of vitamin B12 deficiency in the light of the characteristics of the patients enrolled. This retrospective, clinical study included 38 children with neurological symptoms of vitamin B12 deficiency. Records of 38 patients referred to a single center of the university hospital outpatient child neurology clinic due to neurological symptoms of vitamin B12 deficiency between February 2012 and December 2013 were evaluated retrospectively. Patients aged 0-18 years with symptoms including syncope, dizziness, convulsion, hypotonia, developmental retardation, tremor, ataxia, tingling sensations and paresthesia, blurring of vision, fatigue and concentration difficulty caused by vitamin B12 deficiency were included in the study. Patient neurological findings included syncope $(n=6)$, dizziness $(n=4)$, hypotonia $(n=9)$, inability to sit or walk without support, or gait ataxia $(n=2)$, convulsion $(n=4)$, hand tremor $(n=1)$, tingling sensations and paresthesia $(n=3)$, vision blurring $(n=1)$, fatigue and concentration difficulty $(n=8)$. All patients with neurological symptoms of vitamin B12 deficiency recovered within one month after vitamin B12 supplementation. In conclusion, clinical characteristics of vitamin B12 deficiency are broad and nonspecific and may not be associated with anemia and increased mean corpuscular volume. Since different clinical characteristics can be seen without anemia, awareness and cautious approach are essential in order to avoid severe clinical disease, especially in children from underdeveloped countries.
\end{abstract}

Key words: Central nervous system; Neurologic manifestations; Vitamin B12 deficiency; Infant; Child; Retrospective studies

\section{Introduction}

Nutrition support is very important in all age groups, especially in children and the elderly ${ }^{1,2}$. Nutritional B12 deficiency is rare in children with nonspecific symptoms, including failure to thrive, vomiting,

\footnotetext{
*This paper was presented as oral presentation at the $15^{\text {th }}$ Turkish Pediatric Society Scientific Congress, May 22-25, 2013, Sivas, Turkey.

Correspondence to: Hepsen Mine Serin, MD, Department of Pediatric Neurology, Ege University School of Medicine, 35040 Bornova/İzmir, Turkey

E-mail: hepsenmine@gmail.com

Received October 16, 2017, accepted July 17, 2018
}

anorexia and neurological changes with or without hematologic disturbances. Symptoms cover a broad spectrum, including weakness, tiredness, lightheadedness, rapid heartbeat and breathing, pale skin, soreness, easy bruising and bleeding, sore tongue, gastric upset, weight loss, diarrhea or constipation, lack of motivation and energy, muscle weakness and tingling in the extremities. Other neurological findings include altered sensation, paresthesia in the extremities, gait ataxia, poor vision, dizziness, loss of taste or smell, urinary or fecal incontinence, loss of cutaneous sensation, impaired sense of vibration, proprioception, psychiatric manifestation, memory impairment, personality 
changes, convulsions, hypotonia, developmental delay, orthostatic hypotension, postural orthostatic tachycardia, poor activity and developmental delay. While it is common during infancy and adolescence in developing and underdeveloped countries, a high level of awareness is required in order to prevent permanent neurological damage from B12 deficiency, especially in children with mild symptoms ${ }^{1}$. Adenosylcobalamin and methylcobalamin, two forms of vitamin B12, are co-factors in two enzymatic reactions, either or both of which may impact myelin formation. Plasma homocysteine increases in vitamin B12 deficiency ${ }^{3,4}$. An increased level of homocysteine is related to a number of neurodegenerative diseases associated with neurotoxicity and overstimulation of N-methyl-D aspartate receptors $^{3-8}$. In case of B12 deficiency, the levels of the homocysteine precursor are affected because a decreased S-adenosylmethionine:S-adenosylhomocysteine (SAM:SAH) ratio affects DNA synthesis and cell recycling, since folate cannot be recycled in the absence of cobalamin ${ }^{3-9}$.

The objective of this study was to determine neurological presentations and characteristics of children with B12 deficiency. Since methylation reactions are very important in many parts of the nervous system, cobalamin deficiency leads to a wide range of neurological presentations.

\section{Patients and Methods}

This retrospective study involved children aged 0-18 referred to the university hospital outpatient child neurology clinic in Turkey due to neurological symptoms during the 2012-2013 period. The study group consisted of 38 patients (20 male and 18 female), age range from 9 months to 17 years. Patients were classified according to their neurological signs and symptoms. Symptoms on admission are shown in Table 1. None of the patients had sufficient animal product foodstuffs in their diet. Diagnosis of B12 deficiency was based on serum B12 concentrations below $200 \mathrm{pg} / \mathrm{mL}$. Data concerning sex, age and symptoms of the disease, neurological examination, laboratory investigations and magnetic resonance imaging (MRI), electroencephalography (EEG) and electromyelography (EMG) findings were collected. Laboratory investigations included vitamin B12, folic acid levels, whole blood count, hemoglobin and hematocrit, and mean corpuscular volume (MCV). Patients with neurological symptoms, serum B12 level lower than $200 \mathrm{pg} / \mathrm{mL}$, and with normal folic acid levels were included in the study. None of the patients was on medication during the study, and none had symptoms of any parasitic or duodenal ulcer disease. Ethical approval for the study was obtained from the local ethics committee.

Treatment regimen involved B12 supplementation with bolus injection of $1000 \mathrm{mcg} / \mathrm{mL} \mathrm{B} 12$ (in the form of cyanocobalamin) intramuscularly and repeated every week for four weeks.

\section{Statistical analysis}

Data analysis was performed using the SPSS (Statistical Package for Social Sciences) version 20 data analysis package. One-way ANOVA was used when differences between the groups were evaluated because the variables showed normal distribution. The paired- $t$ test was used because the variance between the two dependent variables was analyzed from normal distribution. Wilcoxon test was used because the variance between the two dependent variables was not different from normal distribution. Kruskal Wallis-H test was used to analyze the variables between the groups, which did not show normal distribution. When Kruskal Wallis-H test yielded significant differences, the groups that differed were identified with the post-hoc multiple comparison test. When one-way ANOVA yielded significant differences, Tukey HSD was used when the variances in the groups were homogeneous, while Tamhane's analysis was used when the variances were not homogeneous. The level of statistically significant difference was set at $\mathrm{p}<0.05$.

\section{Results}

Patient neurological findings included syncope $(n=6)$, dizziness $(n=4)$, hypotonia $(n=9)$, inability to sit or walk without support, or gait ataxia $(n=2)$, convulsion $(n=4)$, hand tremor $(n=1)$, tingling sensations and paresthesia $(n=3)$, vision blurring $(n=1)$, fatigue and concentration difficulty $(n=8)$. Patients were divided into four groups by combining these findings together. Group 1 consisted of patients with syncope and dizziness $(n=10)$; group 2 of patients with hypotonia findings $(n=9)$; group 3 of patients with tingling sensations and paresthesia, fatigue, difficulty in concentrating and 
Table 1. Clinical, radiological and neurophysiological features of patients with vitamin B12 deficiency

\begin{tabular}{|c|c|c|c|c|c|c|c|}
\hline $\begin{array}{l}\text { Patient } \\
\text { no. }\end{array}$ & Sex & $\begin{array}{l}\text { Age at } \\
\text { presentation } \\
\text { (years) }\end{array}$ & Neurological symptoms & $\begin{array}{l}\mathrm{Hb} \\
(\mathrm{mg} / \mathrm{dL})\end{array}$ & $\begin{array}{l}\text { Vitamin } \\
\text { B12 level } \\
\text { (pg/mL) }\end{array}$ & $\begin{array}{l}\text { Cranial MRI } \\
\text { findings }\end{array}$ & Additional test \\
\hline 1 & M & 12 & Syncope & 13.1 & 159 & $\mathrm{~N}$ & Interictal EEG: $\mathrm{N}$ \\
\hline 2 & M & 10 & Syncope & 13.9 & 168 & $\mathrm{~N}$ & Interictal EEG: $\mathrm{N}$ \\
\hline 3 & $\mathrm{~F}$ & 11 & Syncope & 13.9 & 137 & $\mathrm{~N}$ & Interictal EEG: $\mathrm{N}$ \\
\hline 4 & $\mathrm{~F}$ & 13 & Syncope & 12.4 & 130 & $\mathrm{~N}$ & Interictal EEG: $\mathrm{N}$ \\
\hline 5 & $\mathrm{~F}$ & 17 & Syncope & 9.8 & 154 & $\mathrm{~N}$ & Interictal EEG: $\mathrm{N}$ \\
\hline 6 & F & 12 & Syncope & 12.8 & 126 & $\mathrm{~N}$ & Interictal EEG: $\mathrm{N}$ \\
\hline 7 & M & 14 & Dizziness & 15.3 & 144 & $\mathrm{~N}$ & \\
\hline 8 & $\mathrm{~F}$ & 14 & Dizziness & 12.1 & 125 & $\mathrm{~N}$ & \\
\hline 9 & $\mathrm{~F}$ & 15 & Dizziness & 14.3 & 109 & $\mathrm{~N}$ & \\
\hline 10 & M & 7 & Dizziness & 12.2 & 147 & $\mathrm{~N}$ & \\
\hline 11 & M & 24 months & Hypotonia, unable to walk & 11.0 & 143 & $\mathrm{~N}$ & \\
\hline 12 & M & 10 months & Hypotonia, unable to sit without support & 11.5 & 40 & $\mathrm{~N}$ & \\
\hline 13 & M & 9 months & Hypotonia, unable to sit without support & 11.1 & 172 & $\mathrm{~N}$ & \\
\hline 14 & M & 10 months & Hypotonia, unable to sit without support & 11.1 & 160 & $\mathrm{~N}$ & \\
\hline 15 & M & 20 months & Hypotonia, unable to walk & 11.3 & 136 & NA & \\
\hline 16 & M & 22 months & Hypotonia, unable to walk & 12.5 & 188 & $\mathrm{~N}$ & \\
\hline 17 & $\mathrm{~F}$ & 22 months & Hypotonia, unable to walk & 11.5 & 132 & $\mathrm{~N}$ & \\
\hline 18 & $\mathrm{~F}$ & 11 months & Hypotonia, unable to sit without support & 11.0 & 154 & NA & \\
\hline 19 & M & 24 months & Hypotonia, unable to walk & 12.0 & 135 & $\mathrm{~N}$ & \\
\hline 20 & M & 5 & Gait ataxia & 12.5 & 157 & $\mathrm{~N}$ & \\
\hline 21 & M & 5 & Gait ataxia & 11.2 & 196 & NA & \\
\hline 22 & M & 12 & Convulsion/focal & 12.9 & 120 & $\mathrm{~N}$ & Interictal EEG: $\mathrm{N}$ \\
\hline 23 & $\mathrm{~F}$ & 3 & Convulsion/generalized & 11.0 & 143 & NA & Interictal EEG: $\mathrm{N}$ \\
\hline 24 & $\mathrm{~F}$ & 10 months & Convulsion (infantile spasm) & 13.3 & 136 & $\mathrm{~N}$ & $\begin{array}{l}\text { EEG: } \\
\text { hypsarrhymia }\end{array}$ \\
\hline 25 & M & 6 & Convulsion/focal & 12.2 & 167 & $\mathrm{~N}$ & Interictal EEG: $\mathrm{N}$ \\
\hline 26 & M & 15 & Tremor & 15.5 & 135 & $\mathrm{~N}$ & \\
\hline 27 & M & 16 & $\begin{array}{l}\text { Tingling sensation, paresthesia } \\
\text { (in distal part of upper extremities) }\end{array}$ & 14.9 & 104 & NA & $\begin{array}{l}\text { EMG: bilateral } \\
\text { sensorial } \\
\text { neuropathy in } \\
\text { upper extremities }\end{array}$ \\
\hline 28 & $\mathrm{~F}$ & 17 & $\begin{array}{l}\text { Tingling sensation, paresthesia in upper distal } \\
\text { extremities }\end{array}$ & 12.3 & 114 & NA & EMG: N \\
\hline 29 & M & 8 & $\begin{array}{l}\text { Tingling sensation, paresthesia in upper distal } \\
\text { extremities }\end{array}$ & 13.6 & 135 & NA & EMG: N \\
\hline 30 & M & 5 & Vision blurring & 13.4 & 146 & $\mathrm{~N}$ & $\begin{array}{l}\text { VEP: amplitudes } \\
\text { lower than normal } \\
\text { on the right side }\end{array}$ \\
\hline 31 & $\mathrm{~F}$ & 17 & Fatigue, difficulty in concentrating, headache & 13.6 & 92 & $\mathrm{~N}$ & \\
\hline 32 & M & 8 & Fatigue, difficulty in concentrating, headache & 14.1 & 98 & $\mathrm{~N}$ & \\
\hline 33 & $\mathrm{~F}$ & 14 & Fatigue, difficulty in concentrating, headache & 10.9 & 161 & $\mathrm{~N}$ & \\
\hline 34 & M & 17 & Fatigue, difficulty in concentrating, headache & 15.1 & 73 & $\mathrm{~N}$ & \\
\hline 35 & $\mathrm{~F}$ & 7 & Fatigue, difficulty in concentrating, headache & 12.4 & 134 & $\mathrm{~N}$ & \\
\hline 36 & F & 10 & Fatigue, difficulty in concentrating, headache & 12.3 & 141 & $\mathrm{~N}$ & \\
\hline 37 & $\mathrm{~F}$ & 8 & Fatigue, difficulty in concentrating, headache & 12.6 & 144 & $\mathrm{~N}$ & \\
\hline 38 & $\mathrm{~F}$ & 12 & Fatigue, difficulty in concentrating, headache & 13.4 & 163 & $\mathrm{~N}$ & \\
\hline
\end{tabular}

$\mathrm{Hb}=$ hemoglobin; $\mathrm{M}$ = male; $\mathrm{F}$ = female; $\mathrm{EEG}$ = electroencephalography; $\mathrm{EMG}$ = electromyelography; VEP = visual evoked potential; $\mathrm{MRI}=$ magnetic resonance imaging; $\mathrm{NA}=$ not available; $\mathrm{N}=$ normal 
headache ( $\mathrm{n}=11)$; and group 4 of those with convulsion $(n=4)$ or other findings (hand tremor, gait ataxia, or vision blurring) $(\mathrm{n}=4)$.

Demographic, clinical, laboratory and imaging data are shown in Table 1. Thirty-eight patients, 21 male and 17 female, met the selection criteria. The syncope and dizziness group consisted of four boys and six girls, the hypotonia findings group of seven boys and two girls, the tingling sensations and paresthesia group of four boys and seven girls, and the other findings group of six boys and two girls. The mean patient age was 8.51 years. A statistically significant difference was determined among the groups according to age. The age in the hypotonia group (group 2) was significantly lower than in the groups with syncope and dizziness (group 1), and tingling-paresthesia, fatigue, difficulty in concentrating and headache (group 3$)(\mathrm{p}<0.05)$.

Patient mean serum B12 level was $137.18 \mathrm{mg} / \mathrm{dL}$. B12 distribution according to patient groups is shown in Table 2. Comparison of pre- and post-treatment values within the groups revealed that in the hypotonia group, the pre-treatment blood hemoglobin level was significantly lower than the post-treatment level $(p<0.05)$. Pre-treatment blood hemoglobin levels and post-treatment MCV levels in the hypotonia group differed from those in other groups $(\mathrm{p}=0.02$ and $\mathrm{p}=0.035$, respectively).

One patient from group 4, who presented with infantile spasm, exhibited a hypsarrhythmic pattern on EEG, while the three other patients with convulsions had normal interictal EEG. The patient with infantile spasm also exhibited elevated homocysteine level (17 $\mu \mathrm{mol} / \mathrm{L}$ ) (normal range: $5-15 \mu \mathrm{mol} / \mathrm{L}$ ) in the urinary organic acid profile. All four group 4 patients experienced no recurrence of convulsions after vitamin supplementation. Patients with tingling sensations and paresthesia (group 3) underwent EMG. One subject exhibited sensory neuropathy on EMG, while the others had normal results. Another nine group 3 patients presented with developmental motor delay and hypotonia. Four were able to sit without support and five were able to support their weight on their feet one month after vitamin supplementation. Patients who presented with fatigue and concentration difficulty recovered, but their headache persisted. All patients with syncope underwent cardiologic consultation. Patients with dizziness were referred to an otolaryngologist. No pathology was determined on otolaryngologic exami- nation. All patients with syncope underwent pediatric cardiologic examination. Transthoracic echocardiography findings were normal, and no pathological difference was determined in blood arterial pressure values in either standing or supine position. After B12 supplementation (in the form of cyanocobalamin), serum vitamin B12 levels normalized and all symptoms except for headache resolved within one month.

\section{Discussion}

Vitamin B12 is essential for development of the central nervous system. Nutritional vitamin B12 deficiency in infancy is common in countries with low intake of animal products ${ }^{4,6}$. Early treatment prevents severe neurological manifestations. Measurement of vitamin B12 levels can assist in the diagnosis of vitamin B12 deficiency. Homocysteine and methylmalonic acid levels also are elevated in B12 deficiency. Diagnosis of vitamin B12 deficiency should not rely on an abnormal hemoglobin level, hematocrit level or $\mathrm{MCV}$, especially in mild cases $^{10}$. Although clinical neurological manifestations in infants have been described very well in several case studies, the underlying pathology is not yet fully understood ${ }^{4}$.

Neurological signs may usually be expected in infants who are exclusively breastfed and who receive inadequate amounts of vitamin B12. Hypotonia and neurodevelopmental delay are the most commonly reported signs in infants. We observed hypotonia in nine cases. Clinical improvement was observed in all patients after vitamin supplementation.

Diagnosis of vitamin B12 deficiency may not cause an abnormal blood chart, especially in mild cases ${ }^{10}$. Anemia was not a common condition in our study. A significant increase in hemoglobin values was observed only in group 2, which consisted of infants with hypotonia (Table 2). Vitamin B12 deficiency may be a more important factor that particularly affects blood chart in these groups. We attributed the difference in pretreatment hemoglobin levels and post-treatment $\mathrm{MCV}$ levels in the hypotonia group to the age of $\mathrm{pa}-$ tients in this group, which was composed of very young individuals.

Several reports have indicated a correlation between epilepsy and vitamin B12 deficiency ${ }^{11-13}$. Rat studies have suggested that homocysteic acid, a metabolic product of homocysteine, induces convulsions ${ }^{11,12}$. 
Table 2. Distribution of age and laboratory values according to patient groups

\begin{tabular}{|c|c|c|c|c|c|c|c|c|}
\hline & & $\mathrm{n}$ & Mean & Median & Min & Max & SD & $p$ \\
\hline \multirow[t]{5}{*}{ Age (years) } & Group 1 & 10 & 12.5 & 12.5 & 7 & 17 & 2.8 & \multirow{5}{*}{0.001} \\
\hline & Group 2 & 9 & 1.41 & 1.67 & 0.75 & 2 & 0.56 & \\
\hline & Group 3 & 11 & 12.18 & 12 & 7 & 17 & 4.14 & \\
\hline & Group 4 & 8 & 6.48 & 5 & 0.83 & 15 & 4.69 & \\
\hline & Total & 38 & 8.51 & 8 & 0.75 & 17 & 5.68 & \\
\hline \multirow{5}{*}{$\begin{array}{l}\text { B12 levels before } \\
\text { treatment }\end{array}$} & Group 1 & 10 & 139.4 & 140.5 & 109 & 163 & 17.12 & \multirow{5}{*}{0.269} \\
\hline & Group 2 & 9 & 140 & 143 & 40 & 188 & 41.89 & \\
\hline & Group 3 & 11 & 123.55 & 134 & 73 & 163 & 29.32 & \\
\hline & Group 4 & 8 & 150 & 144.5 & 120 & 196 & 23.42 & \\
\hline & Total & 38 & 137.18 & 139 & 40 & 196 & 29.68 & \\
\hline \multirow{5}{*}{$\begin{array}{l}\text { B12 levels after } \\
\text { treatment }\end{array}$} & Group 1 & 10 & 609.4 & 590.5 & 430 & 878 & 168.06 & \multirow{5}{*}{0.989} \\
\hline & Group 2 & 9 & 722.67 & 644 & 345 & 2000 & 509.3 & \\
\hline & Group 3 & 11 & 727.09 & 587 & 339 & 2000 & 452.2 & \\
\hline & Group 4 & 8 & 658.5 & 585 & 300 & 1043 & 279.09 & \\
\hline & Total & 38 & 680.63 & 604 & 300 & 2000 & 368.11 & \\
\hline \multirow{5}{*}{$\begin{array}{l}\text { Blood hemoglobin } \\
\text { levels before } \\
\text { treatment }\end{array}$} & Group 1 & 10 & 12.97 & 12.95 & 9.8 & 15.3 & 1.52 & \multirow{5}{*}{0.02} \\
\hline & Group 2 & 9 & 11.44 & 11.3 & 11 & 12.5 & 0.51 & \\
\hline & Group 3 & 11 & 13.2 & 13.4 & 10.9 & 15.1 & 1.25 & \\
\hline & Group 4 & 8 & 12.75 & 12.7 & 11 & 15.5 & 1.42 & \\
\hline & Total & 38 & 12.63 & 12.45 & 9.8 & 15.5 & 1.38 & \\
\hline \multirow{5}{*}{$\begin{array}{l}\text { Blood hemoglobin } \\
\text { levels after } \\
\text { treatment }\end{array}$} & Group 1 & 10 & 13.42 & 13.55 & 11 & 14.8 & 1.12 & \multirow{5}{*}{0.051} \\
\hline & Group 2 & 9 & 12.19 & 12.3 & 11 & 13.1 & 0.63 & \\
\hline & Group 3 & 11 & 13.12 & 13 & 11.5 & 15.3 & 1.17 & \\
\hline & Group 4 & 8 & 13 & 12.6 & 12.2 & 15.4 & 1.05 & \\
\hline & Total & 38 & 12.95 & 12.75 & 11 & 15.4 & 1.08 & \\
\hline \multirow{5}{*}{$\begin{array}{l}\text { MCV before } \\
\text { treatment }\end{array}$} & Group 1 & 10 & 80.86 & 81.7 & 70.4 & 88.4 & 5.26 & \multirow{5}{*}{0.35} \\
\hline & Group 2 & 9 & 79.04 & 79.5 & 71.5 & 91.1 & 5.81 & \\
\hline & Group 3 & 11 & 82.65 & 80.7 & 78.4 & 89.8 & 4.26 & \\
\hline & Group 4 & 8 & 79.41 & 80.4 & 72.4 & 85.4 & 3.99 & \\
\hline & Total & 38 & 80.64 & 80.55 & 70.4 & 91.1 & 4.91 & \\
\hline \multirow{5}{*}{$\begin{array}{l}\text { MCV after } \\
\text { treatment }\end{array}$} & Group 1 & 10 & 80.4 & 81.35 & 73.5 & 83.4 & 3.51 & \multirow{5}{*}{0.035} \\
\hline & Group 2 & 9 & 77.78 & 77.8 & 73.5 & 81.2 & 2.46 & \\
\hline & Group 3 & 11 & 81.71 & 80.9 & 77.8 & 88.5 & 3.22 & \\
\hline & Group 4 & 8 & 80.4 & 80.35 & 77.3 & 84.7 & 2.24 & \\
\hline & Total & 38 & 80.16 & 80.7 & 73.5 & 88.5 & 3.19 & \\
\hline \multirow[t]{2}{*}{ Group 1} & Blood hemoglobin levels before treatment & 10 & 12.97 & 12.95 & 9.8 & 15.3 & 1.52 & \multirow{2}{*}{0.257} \\
\hline & Blood hemoglobin levels after treatment & 10 & 13.42 & 13.55 & 11 & 14.8 & 1.12 & \\
\hline \multirow[t]{2}{*}{ Group 2} & Blood hemoglobin levels before treatment & 9 & 11.44 & 11.3 & 11 & 12.5 & 0.51 & \multirow{2}{*}{0.006} \\
\hline & Blood hemoglobin levels after treatment & 9 & 12.19 & 12.3 & 11 & 13.1 & 0.63 & \\
\hline \multirow[t]{2}{*}{ Group 3} & Blood hemoglobin levels before treatment & 11 & 13.2 & 13.4 & 10.9 & 15.1 & 1.25 & \multirow{2}{*}{0.72} \\
\hline & Blood hemoglobin levels after treatment & 11 & 13.12 & 13 & 11.5 & 15.3 & 1.17 & \\
\hline \multirow[t]{2}{*}{ Group 4} & Blood hemoglobin levels before treatment & 11 & 13.2 & 13.4 & 10.9 & 15.1 & 1.25 & \multirow{2}{*}{0.722} \\
\hline & Blood hemoglobin levels after treatment & 11 & 13.12 & 13 & 11.5 & 15.3 & 1.17 & \\
\hline Total & Blood hemoglobin levels before treatment & 38 & 12.63 & 12.45 & 9.8 & 15.5 & 1.38 & 0006 \\
\hline & Blood hemoglobin levels after treatment & 38 & 12.95 & 12.75 & 11 & 15.4 & 1.08 & 0.026 \\
\hline
\end{tabular}

$\mathrm{MCV}=$ mean corpuscular volume 
There are also reports of patients with infantile spasm being successfully treated with B12 supplementa$\operatorname{tion}^{14,15}$. In this study, we identified two patients with focal convulsion, i.e. one with generalized convulsion and another one with infantile spasms. The patient with infantile spasm exhibited hypsarrhythmia on EEG and was treated successfully with B12 and adrenocorticotropic hormone. All patients were subsequently seizure-free. The other patient exhibited normal interictal EEG and MRI findings. Vitamin B12 deficiency can also lead to dizziness and syncope. Vitamin B12 is important in the production of adrenaline from noradrenaline. It is an essential cofactor involved in myelin degradation and in the synthesis of catecholamines. Another proposed mechanism is that myelin synthesis is disrupted in vitamin B12 deficiency and may lead to baroreflex dysfunction, affecting the sympathetic regulation of blood vessels and autonomic nervous system ${ }^{16}$. A cause and effect relationship has also been suggested between syncope and postural orthostatic tachycardia syndrome in B12 deficiency ${ }^{17}$. Vision loss in vitamin B12 deficiency has been regarded as secondary to optic neuropathy ${ }^{18-21}$. In the present study, one patient had vision abnormality and pathological visual evoked potential test results. This patient also recovered within a few weeks with B12 supplementation.

Neuropsychiatric abnormalities consist of a wide range of symptoms including chronic fatigue syndrome, mood disorders, attention deficit, mental status and cognitive changes, slow mentation, memory impairment and behavioral abnormalities ${ }^{22,23}$. Patients without macrocytic anemia but with tissue cobalamin deficiency can also develop neuropsychiatric abnormalities ${ }^{22}$. Although only one had anemia, eight of our patients were affected neuropsychologically. The absence of quantitative analysis in terms of neuropsychological tests in patients with fatigue and attention deficit was a limitation of this study. However, the fact that the symptoms resolved in a few weeks after supplementation of vitamin B12 indicates a cause-effect relationship between B12 deficiency and the symptoms in question. Patients who presented with fatigue and concentration difficulty recovered, but their headache persisted. We conclude that headache was not related to vitamin B12 deficiency because the patients did not have anemia. Additionally, polyneuropathy is a common neurological finding in patients with vitamin
B12 deficiency. Polyneuropathy due to cobalamin deficiency is often axonal. Neurophysiological and pathological findings indicate axonal degeneration, whether or not accompanied by demyelination. In this study, three patients were admitted with tingling sensations and paresthesia in distal upper extremities. The pathogenic mechanism of neuropathy in cobalamin deficiency has been attributed to myelin damage involving astrocytes and microglia.

Although we made every effort to establish a large cohort with a wide variety of symptoms of vitamin B12 deficiency, this study still had a number of limitations, as follows: we were unable to screen for homocysteine and methylmalonic acid levels supporting B12 deficiency. Only the patient with infantile spasm underwent urinary and plasma amino and organic acid tests in order to exclude a diagnosis of metabolic disease; and patient symptoms and signs could not be evaluated with neuropsychological investigation.

In conclusion, vitamin B12 deficiency should be considered in patients with congenital hypotonia, syncope, gait ataxia, convulsions, vision loss or vision blurring, neuropathy, dizziness or tremor, even in the absence of anemia. Since nervous system symptoms can precede anemia by months, patients with neurological symptoms should be carefully evaluated in terms of vitamin B12 deficiency with or without associated anemia. Since immediate and accurate treatment prevents progression of the disease, a cautious and aware approach is essential. We believe that this study indicates the importance of screening for vitamin B12 in patients from low-income and populous communities and with the symptoms described.

\section{Acknowledgment}

We are grateful to Baran Oğuz, MD, and all the children who took part in this study, and to their families.

\section{References}

1. Georgieff MK, Ramel SE, Cusick SE. Nutritional influences on brain development. Acta Paediatr. 2018;107(8):1310-21, https://doi.org/10.1111/apa.14287

2. Vranešić Bender D, Kovačević $M$, Hanževački M, Vrabec B, Benković V, Domislović V, Krznarić Ž. Nutritional issues and nutrition support in older home care patients in the City of Zagreb. Acta Clin Croat. 2017;56(4):689-97, https://doi. org/10.20471/acc.2017.56.04.17 
3. Dobrozsi S, Flood VH, Panepinto J, Scott JP, Brandow A. Vitamin B12 deficiency: the great masquerader. Pediatr Blood Cancer. 2014;61:753-5, https://doi.org/10.1002/pbc.24784

4. Dror DK, Allen LH. Effect of vitamin B12 deficiency on neurodevelopment in infants: current knowledge and possible mechanisms. Nutrition. 2008;66:250-5, https://doi.org/ 10.1111/j.1753-4887.2008.00031.x

5. Coppen A, Bolander-Gouaille C. Treatment of depression: time to consider folic acid and vitamin B12. J Psychopharmacol. 2005;19: 59-65.

6. Taşkesen M, Yaramış A, Pirinççioğlu AG, Ekici F. Cranial magnetic resonance imaging findings of nutritional vitamin B12 deficiency in 15 hypotonic infants. Eur J Paediatr Neurol. 2012;16:266-70, https://doi.org/ 10.1016/j.ejpn.2011.08.005

7. Molloy A, Weir DG. Homocysteine and the nervous system. In: Carmel R, Jacobsen DW, eds. Homocysteine in Health and Disease. Cambridge, UK: Cambridge University Press, 2001; p. 183-97.

8. Lipton SA, Kim WK, Choi YB, Kumar S, D'Emilia DM, Rayudu PV, et al. Neurotoxicity associated with dual actions of homocysteine at the N-methyl-D-aspartate receptor. Proc Natl Acad Sci U S A. 1997;94:5923-8.

9. Guerra-Shinohara EM, Morita OE, Peres S, Pagliusi RA, Sampaio Neto LF, D'Almeida V, et al. Low ratio of S-adenosylmethionine to $\mathrm{S}$-adenosylhomocysteine is associated with vitamin deficiency in Brazilian pregnant women and newborns. Am J Clin Nutr. 2004;80:1312-21.

10. Rasmussen SA, Fernhoff PM, Scanlon KS. Vitamin B12 deficiency in children and adolescents. J Pediatr. 2001 Jan;138: 10-7.

11. Incecik F, Hergüner MO, Altunbaşak S, Leblebisatan G. Neurologic findings of nutritional vitamin B12 deficiency in children. Turk J Pediatr. 2010;52:17-21.

12. Mares P, Folbergrovia, J, Langmeier M, Haugvicova R, Kubova H. Convulsant action of D,L-homocysteic acid and its stereoisomers in immature rats. Epilepsia. 1997;38:767-76.

13. Korenke GC, Hunneman DH, Eber S, Hanefeld F. Severe encephalopathy with epilepsy in an infant caused by subclinical maternal pernicious anaemia: case report and review of the literature. Eur J Pediatr. 2004;163:196-201.

14. Malbora B, Yuksel D, Aksoy A, Ozkan M. Two infants with infantile spasms associated with vitamin B12 deficiency. Pediatr Neurol. 2014;51:144-6, https://doi.org/10.1016/j.pediatrneurol.2014.03.001

15. Glaser K, Girschick HJ, Schropp C, Speer CP. Psychomotor development following early treatment of severe infantile vitamin B12 deficiency and West syndrome - is everything fine? A case report and review of literature. Brain Dev. 2015;37(3): 347-51, https://doi.org/ 10.1016/j.braindev.2014.05.006

16. Oner T, Guven B, Tavli V, Mese T, Yilmazer MM, Demirpence S. Postural orthostatic tachycardia syndrome (POTS) and vitamin B12 deficiency in adolescents. Pediatrics. 2014;133: 138-42, https://doi.org/10.1542/peds.2012-3427

17. Ganjehei L, Massumi A, Razavi M, Wilson JM. Orthostatic hypotension as a manifestation of vitamin B12 deficiency. Tex Heart Inst J. 2012;39:722-3.

18. Pott JW, Klein Wassink-Ruiter JS, van Vliet A. Methylmalonic acid and homocysteine assessment in the detection of vitamin B12 deficiency in patients with bilateral visual loss. Acta Ophthalmol. 2012;90:252-3, https://doi.org/10.1111/j.1755-3768.2011.02342.x

19. Pineles SL, Avery RA, Liu GT. Vitamin B12 optic neuropathy in autism. Pediatrics. 2010;126:967-70, https://doi.org/10.1542/peds.2009-2975

20. Chavala SH, Kosmorsky GS, Lee MK, Lee MS. Optic neuropathy in vitamin B12 deficiency. Eur J Intern Med. 2005; 16:447-8.

21. Pandey S, Kalita J, Misra UK. A sequential study of visual evoked potential in patients with vitamin B12 deficiency neurological syndrome. Clin Neurophysiol. 2004;115:914-8.

22. Delva MD. Vitamin B12 replacement. To B12 or not to B12? Can Fam Physician. 1997;43:917-22.

23. Briani C, Dalla Torre C, Citton V, Manara R, Pompanin S, Binotto $\mathrm{G}$, et al. Cobalamin deficiency: clinical picture and radiological findings. Nutrients. 2013;5:4521-39, https://doi. org/ 10.3390/nu5114521 


\section{Sažetak \\ NEUROLOŠKI SIMPTOMI NEDOSTATKA VITAMINA B12: ANALIZA PEDIJATRIJSKIH BOLESNIKA}

\section{H. M. Serin i E. Acar Arslan}

Vitamin B12 jedan je od ključnih vitamina koji utječe na razne sustave u organizmu uključujući središnji živčani sustav. Vitamin B12 ima važnu ulogu u metabolizmu živčanog sustava, iako njegova uloga u patološkim stanjima nije u potpunosti razjašnjena. Namjera ovoga istraživanja bila je naglasiti važnost rane dijagnoze nedostatka vitamina B12 u svjetlu karakteristika bolesnika uključenih u istraživanje. Ovo retrospektivno kliničko istraživanje uključilo je 38 djece s neurološkim simptomima nedostatka vitamina B12. Retrospektivno su analizirani podaci za 38 djece upućene u ambulantu za dječju neurologiju jedne sveučilišne bolnice zbog neuroloških simptoma nedostatka vitamina B12 između veljače 2012. i prosinca 2013. godine. Uključeni su bolesnici u dobi od 0 do 18 godina sa sljedećim simptomima uzrokovanim nedostatkom vitamina B12: sinkopa, vrtoglavica, konvulzije, hipotonija, zastoj u razvoju, tremor, ataksija, trnci i parestezije, zamagljen vid, umor i otežana koncentracija. $U$ bolesnika su zabilježeni sljedeći neurološki nalazi: sinkopa $(n=6)$, vrtoglavica $(n=4)$, hipotonija $(n=9)$, nemogućnost da sjedi ili hoda bez potpore, ili ataksija u hodu $(n=2)$, konvulzije $(n=4)$, tremor ruku $(n=1)$, trnci i parestezija $(n=3)$, zamagljen vid $(n=1)$, umor i otežana koncentracija $(n=8)$. Svi bolesnici s neurološkim simptomima nedostatka vitamina B12 oporavili su se kroz jedan mjesec nakon nadomještanja vitamina B12. U zaključku, kliničke značajke nedostatka vitamina B12 široke su i nespecifične te ne moraju biti udružene s anemijom i povećanim srednjim korpuskularnim volumenom. Kako se razne kliničke značajke mogu zapaziti bez anemije, svijest o ovom nedostatku i pažljiv pristup bitni su kako bi se izbjegla teška klinička bolest, poglavito u djece iz manje razvijenih zemalja.

Ključne riječi: Središnji živčani sustav; Neurološke manifestacije; Vitamin B12, deficijencija; Dojenče; Dijete; Retrospektivne studije 